\title{
Lina Bo Bardi: Evolution of Cultural Displacement
}

SMILJA MILOVANOVIC-BERTRAM

University of Texas at Austin

In recent years much has been written and exhibited regarding LIna Bo Bardi, the Italian/Brazilian architect (1914-1992). This paper aims to look at the phenomenon of cultural displacement and the dissemination of her design thinking as a major female figure in a male dominated profession. This investigation is distinguished from others in that it addresses the importance of regional and cultural influences that formed Lina's design philosophy in her early years in Italy. Cultural displacement has long played a significant role in the creative process for artists. Often major innovators in literature are immigrants as elements of strangeness, distance, and alienation all contribute to their creativity. The premise is that critical distance is paramount for reflection as a change of context unfolds unforeseen possibilities.

Displacement was a consistent element throughout the trajectory of Lina's architectural career as she moved from Rome to Milan, from Milan to Sao Paolo from Sao Paolo to Bahia and back to Sao Paolo. Viewing this form of detachment and dislocation permits insight into her career and body of work as displacement mediates the paradoxical relationship between time and space.

The paper will examine three distinct periods in her career. The first period is set in Rome, where she assimilated the city, showed artistic aptitude and spent her university years studying under Piacentini and Giovannoni. The second period is set in Milan, where she developed impressive editorial and layout skills in publications work with Gio Ponti and Bruno Zevi. and was influenced by Antonio Gramsci's writings. The third is set in Brazil, where she builds and evolves as an architect via what she absorbed in Rome, wrote in Milan, and finally realized in Brazil.
After Italy's collapse in WWII Lina writes, draws, edits, critiques the plight of the Italians in need of better housing and circumstances. She leaves Milan with her new husband, PM Bardi (a prominent journalist, art critic) for Brazil. In Sao Paolo she absorbs the optimism and positive direction of Brazil. Her early design work in Brazil echoes European modernism, but when she travels to Bahia and becomes aware of the social conditions, she draws from her Italian experiences of and ideas of transforming lives through craft. Her architectural projects become directly responsive to the culture of Bahia and the politics of poverty. Lina's design thinking evolves and parallels George Kubler's study, The Shape of Time, and the history of man-made objects by bridging the divide between art and material culture.

ITALY

This paper addresses influences that formed Lina Bo Bardi's design philosophy during her early years in Italy that would later transform her mature work in Brazil. Lina Bo Bardi (1914-1992), Italian born, educated in Rome, trained in Milan, immigrated to Brazil after World War II. In Brazil she evolved from her Modernist training to a uniquely humanist architect influenced both by the culture of her native Italy and the indigenous culture of Bahia in her adopted Brazil.

I contend that cultural displacement acted as an idea generator for her work in Brazil. By cultural displacement I am referring to physical and metaphorical dislocation's effect on spatial imagination. Cultural displacement has long played a significant role in the creative process for architects and artists. Often major innovators in literature and the arts are immigrants for whom elements of strangeness, distance, otherness and alienation contribute to their creativity. Critical distance is paramount for reflection as a change of context unfolds unforeseen possibilities. Otherness, alterity, culture-all these terms gain new light if we think of the post World War II period as a time of de-colonization and a time of deep transformations in the field of architecture. ${ }^{1}$ 
Three factors that contributed to Lina's development in Italy include her education in Rome, her Milan period work with Gio Ponti in journalism, and the leftist writings of the Italian communist Antonio Gramsci.

Lina was trained at the University of Rome-Sapienza under Marcello Piacentini (1881-1960) and Gustavo Giovannoni (1881-1960), two very staid traditionalists. Piacentini devised a Fascist architectural style that was midway between the neo-classicism of the Novecento Italiano group and the rationalism of Grupo 7 (Giuseppe Terragni, Adalberto Libera and others). Giovannoni, a civil engineer and scholar of urban history, extended the notion of conservation from a single building to a wider context. He created not only cultural guidelines, but also technical tools concerning areas of legislation, urban planning, and architectural restoration. ${ }^{2}$

Lina graduated in Rome and left for Milan, a city more open, both politically and culturally. In Milan she formed a studio with her colleague Carlo Pagani and both worked with Giò Ponti creating content for the journals Domus and Quaderni di Domus. As Lina said, "I went to Milan, I ran way from ancient ruins restored by fascists. Rome was the city that had stopped, it was where fascism was. All of Italy was somewhat stopped. Except for Milan." ${ }^{3}$

Italy was an ideological swamp during the 1930 s and 40s. On one side the Rationalist architect Giuseppe Terragni (1904-43) designed and built the Casa del Fascio in Como, later to die after enlisting in Mussolini's army; Giuseppe Pagano (1896-1945), architect and long time editor of Casabella supported Rationalist architecture but was critical of the Fascists and died in a concentration camp. ${ }^{4}$

Meanwhile, the Marxist Antonio Gramsci (1891-1937) was writing in prison, reviewing Marxist concepts and proposing new societal and political approaches that included historicism and the role of intellectuals. Gramsci was one of the founders of the Italian Communist Party, a brilliant thinker and writer as well as a devoted militant. Gramsci was imprisoned by Mussolini's Fascists in 1926 and died there 11 years later.

Gio Ponti took an alternative position. As architect, designer and editor of Domus magazine, his work explored the richness of Italy's classical heritage and opened a clear polemic against strict functionalism. Central to Ponti's work and design philosophy was his "Casa all'italiana". For Ponti a house should never be purely a machine for living, but the setting of Italian life as proposed in his Domus writings. Ponti viewed Le Corbusier's machine as too cold and brutal for the Italian lifestyle and believed it could be enriched with local materials using traditional building forms and the integration of interior and exterior spaces in a Mediterranean lifestyle. 5 Ponti did support the advancing practical technological innovations for hygiene, etc., but his separation of style and technology was criticized by Rationalists such as Grupo 7. ${ }^{6}$

During the years of World War II there were few architectural commissions, so Ponti funneled his efforts into writing, painting, and projecting ideas for well-designed housing and art for the masses. Ponti left Domus over an editorial dispute and launched Lo Stile (1941-47) an arts magazine for everyman, not making a distinction between art and craft. Entire issues were devoted to reconstruction, unification, city planning, and homes for everyone, all relevant topics during World War II and its aftermath. Ponti's mission stated that "over 20 million rooms" are "needed by Italy." 7 Lina, along with Carlo Pagani, contributed articles, innovative artwork, and layouts to Lo Stile for an audience that was not necessarily part of the art world. (see Figure 1 )

Gio Ponti introduced Lina to concepts of regional Italian vernacular as represented by his "Casa all'italiana", a fresh look at regionalism and influential in shaping Lina's view of vernacular Brazil. Ponti's belief that architecture should be at the forefront of social change became a vision that Lina carried throughout her career, especially in Brazil.

In 1944 Lina became Deputy Director of Domus at age 30 (until it closed in 1945). Later in the post-war years Lina helped found the weekly magazine A-Attualita, Architettura, Abitazione, Arte with Bruno Zevi. The magazine's financial support was eventually withdrawn because of its liberal leftist content.

Lina's commission from Milano Sera to travel, survey and document living conditions on the Italian peninsula exemplifies the milieu of Italy at World War II's end in 1945. The newspaper Milano Sera was the brainchild of communists and socialists, a newspaper with few resources and a leftist agenda. Accompanied by Carlo Pagani, their mission was cut short by the appalling conditions encountered as they traveled south. Instead of discovering indigenous examples of local authentic meaning, they found total devastation. They returned to Milan disappointed in prospects for the future. Lina probably did not participate directly in armed resistance, but during this period she associated with artists and intellectuals of the underground movement where her political views evolved with a strong emphasis on social criticism. ${ }^{8}$ Also important were the political and philosophical writings of Italian Marxist Antonio Gramsci during her Milan years as she witnessed the destruction of Italy during World War II.

\section{BRAZIL}

Returning to Rome from Milan, Lina married the art expert, dealer and journalist Pietro Maria Bardi. The couple moved to Brazil in 1946. First in Rio de Janiero and later in Sao Paolo, Lina moved among an elite group of European Brazilians. In 1950, Lina and P.M. Bardi founded a new art design magazine, Habitat. Using the expertise she developed working with Gio Ponti and Domus in Milan, she was publisher, editor, illustrator and journalist. Lina also founded a furniture design studio Studio de Arte e Arquitetura Palma. As a furniture designer her Bowl Chair (1951) became a classic.

Lina's first project in Brazil, her own home, the Glass House (Casa Vidro) Sao Paolo, 1951, reflected her own euro-modernisms. Casa de Vidra is a Corbusier type Dom-Ino house with glass enclosure sandwiched between two thin slabs of concrete on slender piloti. Built on a slope in the remnants of the original rain forest, the impression is a one-ness with nature. The glass walls were not seen as a transparent, but rather a reflective surface with the exterior vegetation acting as a landscape wall. Lina conveyed Italian Rationalist architecture with a Brazilian contextual twist.

The Crystal Garden House (Valeria Cirella House), Sao Paolo, 1958 was 


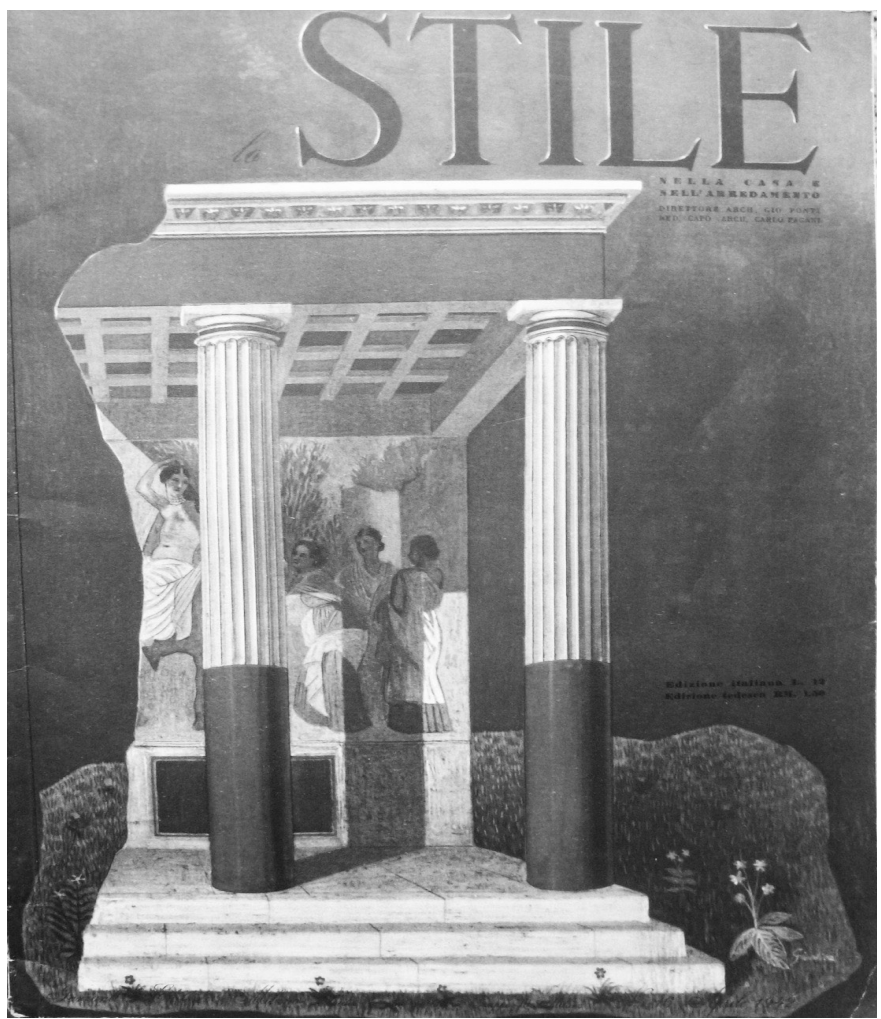

Figure 1: Lo Stile magazine cover, Milan 1942 by Lina Bo and Gio Ponti

Figure 2: SESC Pompeia Factory Project 1977-86, Sao Paolo built 7 years after the Glass House and a few 100 meters away. It was built using traditional Brazilian construction techniques and materials. At first glance, the Crystal Garden House appears the antithesis of her glass house, but the use of an actual vegetation wall and columns of tree trunks echo the Glass House. Lina was responding to Brazil's cultural and social context in seeking her own stance and perspective.

Her design for the new Sao Palo Museum of Art (MASP), 1968, was sited on Avenida Paulista, a stylish and important avenue, preventing obstruction of the city view below. Two enormous pre-stressed concrete beams, resting on equally massive piers, traverse the length of the site in parallel and suspend a voluminous box containing the museum's main exhibition and administrative spaces. The public space provided on ground level became a public offering for citizens' use, whether commercial, social, or political. Brutalist towers support elegant International Style glazing and an open floor plan. Exhibition areas were radical in their layout. Artwork was unframed between glass sheets with no intentional sense of chronology or other guided progression. Visitors wander through unsorted artwork, each its own event. Lina took a lesson from Gio Ponti that art should be accessible to every man.

When Lina arrived to Bahia in 1958, her reactions to the inequitable social and political conditions were central in her turn from the lexicon of rationalism to the vocabulary of politics in emphasizing the importance of popular culture. It was not a displacement in spatial terms, but in ideology. ${ }^{9}$ An important historic parallel between

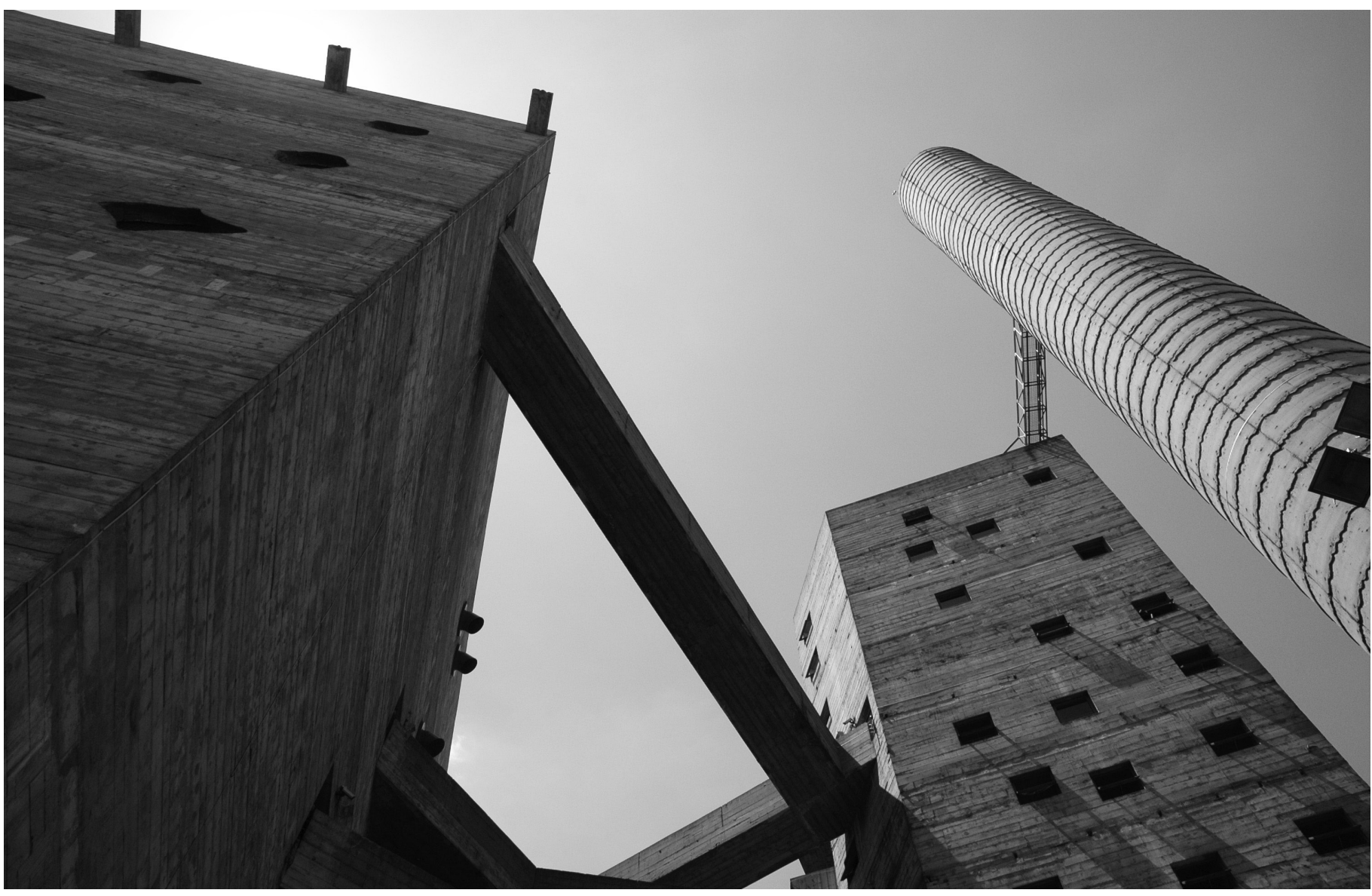


Italy and Brazil was the "Southern Question" (La questione meridionale,), an ongoing political and social issue in Italy after World War I. According to the Marxist Gramsci, the bourgeoisie of Italy's north had subjugated not only the working class of the north but also the peasants of the south. Gramsci's writings opened up a broad inquiry into the social and cultural conditions of subordination and exclusion. ${ }^{10}$ Italy is still divided along Northern and Southern regions, with Northern Italy more economically developed than the agrarian and poorer South. This is analogous to Southern Brazil's region being more developed than the poorer Northeast and Bahia regions. Southern Italy is rich culturally, but its climate, geography and history left it impoverished, with illiteracy, and lacking a middle class. Similarly, Bahia is a culturally rich region where social and political issues center on agrarian and voting rights reform, poverty, and illiteracy.

Lina arrived in one context to Sao Paolo, in another to Bahia and responded differently to the cultural forces of each. In Salvador she faced the challenge of cultural heritage when she chose to install a museum in a 16th century structure, the Solar do Unhão. The rehabilitation of the complex of buildings somehow summarizes the tense relations between preservation, conservation and modernism, order and innovation, and the role of modern architects within Brazil following the formalism of Oscar Niemeyer's designs (among others).

The Solar do Unhao project, 1963, is a complex of historic buildings (including a manor house and sugar mill) to accommodate the Bahia Modern Art Museum (MAMB). As an example of Lina's efforts in adaptive re-use, she once suggested, "it is necessary to consider the past as a historical present, still alive." ${ }^{11}$ In Lina's project to construct and restore the Solar do Unhao, the Museum of Popular Art presented the Northeast Exhibition, 1963, curated and designed by Lina. Brazilian poverty and its everyday objects were presented as both aesthetically and politically appropriate. Lina's exhibition was meant to show primitive crafts in a technical manner -as utilities, examples of simplification.

"I made the most of my experience in the northeast of Brazil. A lesson of popular experience, not as folkloric romanticism but as an experiment in simplification." 12

With the help of her contacts in Rome, Lina tried, in 1965, to promote exposure of the Northeast exhibition. Brazil's Foreign Ministry intervened, claiming that the exhibit could not be displayed outside the country and the exhibit was boxed and sent back to Brazil. Bruno Zevi, a fervent critic of Brasilia's architecture, wrote an article for Expresso di Roma in April, 1965 titled, "The Art of the People Terrified the Generals." Lina was already back in Sao Paolo, and her years in Bahia ended with the coup d'état by the military dictatorship in $1964 .{ }^{13}$

Brazil's military dictatorship, from 1965 to 1980, was a period of few substantial architectural commissions due to Lina's very liberal political sentiments. During this time she designed sets and costumes for avant-garde theater and cinema productions. Lina was an innovator in exhibit design and curatorship.
Perhaps Lina's most important commission was SESC Pompeia Factory (Sao Paolo, 1977-86). The project is a former barrel factory converted into a workers' social and cultural center. It reflects her mature design thinking as an adaptive re-use project in an industrial area. The original factory structure was not torn down and two concrete towers were added. The buildings were constructed in existing space and within time constraints, as flexible and cheaply as possible. This project synthesized her social and political consciousness adopted from both Ponti and Gramsci. (see Figure 2)

Each of Lina's displacements from Rome to Milan to Sao Paolo to Bahia involved a cultural and ideological displacement that informed her design thinking. Throughout her later work in Bahia Lina fervently incorporated cultural and social sustainability into her design work. Her work in preservation and adaptive re-use was far ahead of its time.

Certainly, observing Lina's work there are subjects and characteristics of her design process that are very relevant to current topics and concerns in global architecture.

Most importantly, Lina, throughout her work, promoted the original mission of the architect as an agent for social change, advocating the necessity of political engagement. ${ }^{14}$

\section{ENDNOTES}

1. Kenneth Frampton, Modern Architecture: a Critical History (London, Thames and Hudson, 1992) Chapter 3.

2. Zueler R.M. de A. Lima, Lina Bo Bardi (New Haven, Yale University Press, 2013) 10.

3. Marcello Ferraz, editor, Lina Bo Bardi (Milan, Edizaione Charta) 9.

4. Smilja Milovanovic-Bertram and Silvana Rubino "The Spirit of Lina Bo Bardi: Design as Global Exchange" FAPESP Proposal 2015, 2.

5. F. Marcello, "Gio Ponti and the Casa all'italiana: Fascist Notion of Domestic Space" (www.researchgate.net/publication/256067426) 1-5.

6. Maristella Casciato, "The Casa all'italliana and the idea of modern dwelling in fascist Italy" Journal of Architecture vol 5 no 5 (2000): 337-338.

7. L.L. Ponti, Gio Ponti: the Complete Work 1923-1978 (Cambridge, M.I.T. Press, 1990) 139.

8. Zueler R.M. de A. Lima, 28.

9. According to my colleague, Professor Silvana Rubino of Universidade Estadual de Campinas, Sao Paolo, Gramsci's writings would appear again in Lina's archives in Sao Paolo.

10. Nadia Urbinati, "From the Periphery of Modernity: Antonio Gramsci's Theory of Subordination and Hegemony" in Political Theory vol 26 no 3 (June, 1998) 371.

11. Zueler R.M. de A. Lima, 2.

12. R.J. Williams, Brazil: Modern Architecture in History (Reaktion Books, 2009) 9-10.

13. Zueler R.M. de A. Lima, 115

14. My colleague, Professor Silvana Rubino of Universidade Estadual de Campinas, Sao Paolo, Brazil, collaborated on topics developed in this paper. 